\title{
Pedagogical Skills Exercise as an Alternative to Increase The Teaching Ability of Pre-Service Chemistry Teachers at Field Experience Practice
}

\author{
Mohan T. Mashuri ${ }^{1,2, *}$ Suyatno Suyatno ${ }^{1}$ Utiya Azizah $^{1}$
}

\author{
${ }^{1}$ Doctoral Program of Science Education, Postgraduate of Universitas Negeri Surabaya, Indonesia. \\ ${ }^{2}$ Universitas Islam Negeri Mataram, Indonesia. \\ ${ }^{*}$ Corresponding author.Email: mohan.19004@mhs.unesa.ac.id
}

\begin{abstract}
This study aims to determine the effect of providing Pedagogical Skills Excercise (PSE) on the teaching ability of preservice chemistry teachers in the Field Experience Practice (FEP). The PSE used in this study consist of three different aspects, namely the skill of developing teaching materials, the skill to manage the classroom, and the skill to carry out the evaluation process. The FEP program is created as part of student teachers' curricula created by the university in collaboration with random schools in a specific area. This study was carried out in two different phases, first, the PSE process was given to the pre-service chemistry teacher, second, the FEP program was conducted by a pre-service chemistry teacher at a random school selected by the university (rular, urban, or remote schools). Eighteen pre-service chemistry teachers of Islamic University of Kalimantan Muhammad Arsyad Al Banjari Banjarmasin participated in this study. This study starts from the second semester of the 2016/2017 school year until the first semester of the 2017/2018 school year. The data were collected through observation, interview, and test. The results showed that the implementation of PSE could improve the teaching ability of pre-service chemistry teachers in FEP. The average score of all participants in all aspects is increased from 60.5 to 82.5 .
\end{abstract}

Keywords: Pedagogical skills, Pre-Service teacher, Field experience practice.

\section{INTRODUCTION}

The teacher plays an important role in the implementation of the learning process at school [1][2][3][4][5]. Every program or curriculum that has been designed both nationally or locally by each school will not be able to run optimally if the teacher is unable to apply for the program effectively and efficiently. This is in line with the contents of constitution number 14 the year 2005 concerning teachers and lecturers which states that teachers are professional educators that should educate, teach, guide, direct, train, and evaluate the learning process [6]. This is also stated in the minister of national education regulation number 16 the year 2007 concerning standards of academic qualifications and teacher competencies, it explained that to obtain professional criteria, each teacher is required to meet academic qualifications and competency standards that apply nationally [7].
Chemistry as one of the science subject at school requires approaches, techniques, strategies, and learning models that are specified by the characteristics of chemistry itself [8][9][10][11][12][13][14] [15][16][17][18][19][20][21][22][23][24][25]. Mastery of the characteristics of the field of chemistry can only apply to chemistry teachers with sufficiently high teaching hours. Many researchers try to maximize the learning of chemistry from various aspects. Some researchers look at the material aspect [8][9][10][11][12][14][16][17[18][19][20][21][22][24][ $25]$, some of them try to use a variety of models in learning [10][11][13][14][15][23], others use media and various games to improve the chemistry learning process $[8][9][12][14][16][17][18][19][20][22][24][25] \quad$ and some try to bring chemistry closer to the culture and everyday life of students [21]. This shows that chemistry as a subject has distinctive and unique characteristics compared to other subjects. 
For chemistry education department students who are preparing to become a teacher or even a fresh graduate, this is a pretty big challenge. Not only because preservice chemistry teacher does not yet have educator certificates but also because they need time to adapt to the conditions of the learning and teaching environment in schools. Different types of public, private, or Islamic boarding schools will make a difference in the management of education. In addition, the differences in student characteristics and the supporting facilities owned by the school will also greatly determine how students learn and how the teacher teaches.

Many ways have been taken by the government to ensure the achievement of the maximum level of professionalism of teachers. To fully support these efforts, all components of education implementers in Indonesia need to take an appropriate and sustainable approach in their respective fields. At the tertiary level of education, each educational program has an obligation and interest to be able to maximize the pedagogical competencies required by a pre-service chemistry teacher before going to school.

One step that can be taken is to provide pedagogical skills exercise for pre-service teachers as a provision in carrying out learning in schools [26][27][28][29]. The pedagogical skills or competency component referred to in this study is by that described in the national education ministerial regulation number 16 the year 2007 concerning standards of academic qualifications and teacher competencies, which consist of abilities; (1) mastering the characteristics of students (2) mastering learning theory and principles of learning, (3) developing curriculum (4) organizing educational learning, (5) utilizing information and communication technology for the benefit of learning, (6) facilitating the development of potential students, (7) communicating effectively with students, (8) conducting assessment and evaluation of learning processes and results, (9) utilizing the results of assessments and evaluations for the benefit of learning, and (10) taking reflective actions to improve the quality of learning [7].

This research further simplifies the teacher competencies as stated in the national education ministerial regulation number 16 the year 2007 concerning standards of academic qualifications and teacher competencies into three basic skills that must be owned by a teacher in learning, namely; (1) planning (skills in developing teaching materials),

(2) implementation (class management skills), and

(3) evaluation (skills in carrying out learning assessments). Furthermore, to support the achievement of these competencies or skills, researchers provide Pedagogical Skills Excercise (PSE). PSE as a program integrated with microteaching. PSE not only provides basic teaching skills such as microteaching but also seeks to provide training for the pre-service chemistry teacher to be able to have the latest skills in carrying out learning. One of them is the application of learning technology.

PSE which is integrated with microteaching seeks to provide habituation for pre-service chemistry teachers who are not familiar with the learning process. Previously, pre-service teachers only obtained theories on how to teach and had not applied them directly. For this reason, PSE bridges the gap between theory and practice, making it possible for pre-service teachers to gain experience and reflect on the learning process. Not only that, in its application, the PSE provided facilitates student-teacher candidates to be able to collaborate with colleagues, adapt to the use of technology in the learning process, and take advantage of the latest conditions in everyday life to be used and utilized in the learning process. Some of these important points make the PSE given a little different from microteaching in general because microteaching tends to focus on basic teaching skills.

\section{METHODS}

This research is quasi-experimental research that is intended to determine the effect of providing Pedagogical Skills Excercise (PSE) to the student as pre-service chemistry teachers on their Field Experience Practices (FEP) score. While the design applied was pretest and posttest design. The research was conducted at the Islamic University of Kalimantan Muhammad Arsyad Al Banjari Banjarmasin, South Kalimantan Province, Indonesia.

The implementation of this research takes two semesters, the second semester of the 2016/2017 school year (from March 2017 to July 2017) to the first semester of the 2017/2018 school year (from September 2017 to January 2018), or in other words, the research conducted from March 2017 to January 2018. This study observed eighteen students as the pre-service chemistry teachers in the chemistry education department at the Islamic University of Kalimantan Muhammad Arsyad Al Banjari Banjarmasin. The sample in this study were all students of the 7th semester who carried out FEP in schools.

This study then compares the teaching scores obtained by pre-service teachers before taking the PSE (as a pretest) and after carrying out the FEP process at school (as a posttest). PSE scores relate to three main 
Table 1. Components of PSE

\begin{tabular}{|c|l|l|}
\hline No & \multicolumn{1}{|c|}{ Components } & \multicolumn{1}{|c|}{ Aspects } \\
\hline 1 & $\begin{array}{l}\text { Planning/Preparation skills (skills in } \\
\text { developing teaching materials) }\end{array}$ & $\begin{array}{l}\text { Appearance; skills for opening and closing lessons; the ability to show objectives, } \\
\text { (class management skills) } \\
\text { apperception, or motivation of the study; mastery of the material; use of language; } \\
\text { systematic presentation; questioning skills; skills to provide reinforcement; teaching } \\
\text { methods; class conditioning; time allocation skill. }\end{array}$ \\
\hline 3 & $\begin{array}{l}\text { Evaluation skills (skills in carrying } \\
\text { out learning assessments) }\end{array}$ & \begin{tabular}{l} 
Conduct learning assessment \\
\hline
\end{tabular} \\
\hline
\end{tabular}

aspects, namely aspects of planning, implementation, and evaluation of the learning process. The scores of preservice chemistry teacher students were obtained using test instruments through observation, interviews, and performance tests (microteaching). The FEP score was obtained using a school practice assessment by the school's chemistry teacher.

\section{RESULTS AND DISCUSSION}

\subsection{Pedagogical Skills Excercise (PSE)}

Pedagogical Skills Exercise (PSE) has unique characteristics. With the different characteristics of a preservice chemistry teacher, the characteristics of the PSE given will also be different for each class and for each teacher. One example is what happened to pre-service chemistry teachers in the Chemistry Education Study Program of Universitas Islam Kalimantan Muhammad Arsyad Al Banjari Banjarmasin.

This study uses PSE as a tool to improve FEP Scores. The PSE in this study consists of three main components as listed in table 1. The PSE is carried out within one semester in a microteaching procedure. After that, the final results of the exercise are assessed by the researcher as the lecturer of the course. Meanwhile, the concept of giving PSE to pre-service chemistry teachers is as shown in figure 1.

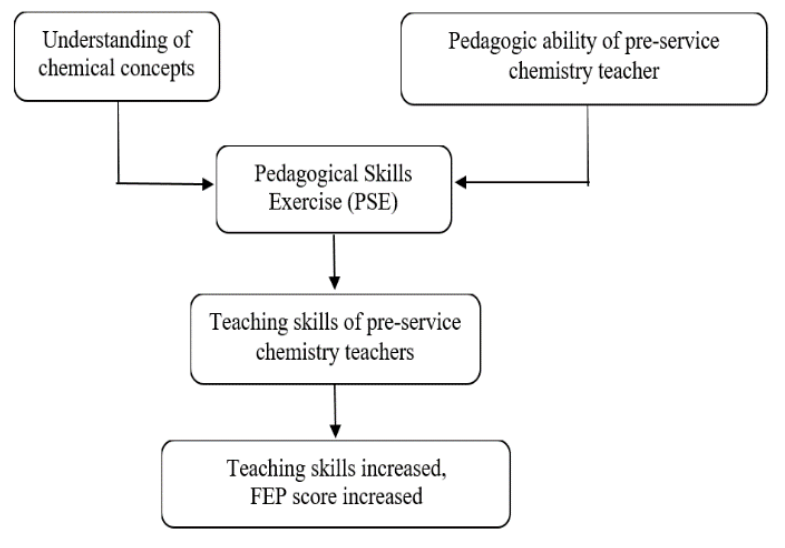

Figure 1 Concept of giving PSE for pre-service. chemistry teacher.

\subsubsection{Preparation Skills}

In the preparation of the learning process, the researcher found that in the preparation of the syllabus, the prospective chemistry teacher students did not have significant difficulties. This is because, in the preparation of the syllabus, students are familiar with the standard format that has been determined. However, in the implementation of PSE, researchers found that the preservice chemistry teachers experienced obstacles in preparing their lesson plans.

Six of the eighteen students (33.33\% of the students) have not been able to prepare lesson plans properly and correctly. Through this case, it can be ensured that the pre-service chemistry teachers need to get more training to develop their skills in creating lesson plans. The preparation of a lesson plan does take more time because it contains all the components of learning, starting from the use of learning resources, media, and learning models. 
Pre-service chemistry teachers have a weakness, namely their tendency to use only discussion and presentation techniques. In this case, the teacher becomes the main source of the learning process. This condition is based on the characteristics of chemistry which consist of various abstract concepts. So that pre-service chemistry teachers choose to use these techniques. The PSE that was carried out tried to provide learning models and concrete variations in the form of using learning media as an alternative that can be used by pre-service chemistry teachers.

In terms of preparing learning assessment instruments that will later be used in evaluating the learning process, pre-service chemistry teachers tend to only use the form of multiple-choice questions or short essays. Thus, PSE equips pre-service chemistry teachers with the use of google forms and internet-based assessments to expand knowledge and variations in the assessment of the learning process by pre-service chemistry teachers.

\subsubsection{Process Skills}

Concerning the learning process, pre-service chemistry teachers do not have obstacles in opening the learning process. However, some pre-service chemistry teachers have problems motivating students at the beginning of the learning process. They assume that the motivation is conveying wise words taken from the sayings of prominent figures or books. So that before starting the lesson they convey words of wisdom such as "effort will not betray the results" thus students are asked to study and work hard. This should not be wrong, but it will be inaccurate because it is not related to the chemistry learning process carried out by them.

Pre-service chemistry teachers should provide the view that the chemistry material to be taught is beneficial in students' daily lives and has a direct impact on problem-solving. Thus students will be motivated to learn the subject that is being taught. An example is by giving examples of metal corrosion and its prevention efforts to students, thus students will be interested because students in everyday life often encounter these problems.

Another unique condition is that twelve out of eighteen students $(66.67 \%$ of students) experienced obstacles in the use of the appropriate language of instruction. Students often use a mixture of Bahasa and traditional language (Banjar) in the learning process. The use of regional languages in certain areas is not a problem, but in the classroom, during the learning process, it will be detrimental for students from other regions. This shows that the provisioning of students in Bahasa still needs to be improved. The high heterogeneity of ethnicity, language, and culture in
Indonesia, especially in Kalimantan, makes everyone accustomed to using regional languages as an introduction to socializing in the community. Due to the daily habit of students using the Banjar language, preservice chemistry teachers have difficulty using Bahasa fluently. This shows that the provision of students in the application and theory of the Indonesian language still needs to be improved.

Another obstacle experienced by students in the use of PSE is that students are not accustomed to organizing systematic learning materials properly. This happens because students are not accustomed to being in a position as a teacher [30]. Students become nervous and uneasy in delivering the learning materials that are being taught. For example, for the subject of Nomenclature of Compounds, students teach the sub-material of nomenclature of binary compounds first compared to an explanation of the rules for naming chemical compounds, where students should first explain the rules of nomenclature for chemical compounds, then explain the nomenclature of binary compounds and then nomenclature of complex compound.

Related to the implementation of teaching and learning activities, another difficulty experienced by students is the management of time. In the use of PSE students tend to maximize time to complete the materials so that the average student carrying out core activities exceeds the time allocation that has been planned in the lesson plan. For example, students allocate 20 minutes for core activities but end up in 30 minutes and miss the closing activities. This then causes the students to rush to carry out the evaluation process at the end of each meeting. Understanding the various constraints experienced by pre-service chemistry teacher students, researchers sought to provide maximum reinforcement and retention.

Another problem experienced by pre-service chemistry teachers is their low literacy in using technology. Prospective chemistry teacher students tend to teach using the question and answer method that only uses the board. So that in the implementation of PSE, prospective teacher students are given provisions and introductions to various technologies to support learning such as the use of animation, image, and video. As several studies have shown the importance of literacy and the use of technology by teachers in supporting the achievement of learning objectives [1][2][3][4][5].

In PSE, prospective teacher students are also given alternative uses of the latest learning media and games to support the achievement of learning objectives. The learning media is expected to increase students' motivation and interaction in the learning process. Some of these media include; smart cards, truth and dare [8] 
box question [9], snakes and ladders [12], scrapbook [14], dartboard [16], crosswords [17], KOKAMI [18], UNO card [20], and comic [22].

\subsubsection{Evaluation Skils}

Pre-service chemistry teachers make questions in the form of multiple-choice questions or short essays. Fourteen out of eighteen students $(77.78 \%$ of students) compile learning evaluation questions in the form of multiple-choice while the remaining four out of eighteen students (22.22\% of students) arrange questions in essay form. Pre-service chemistry teachers tend to take questions from textbooks or practice questions on the internet directly. This causes the formation of questions compiled by pre-service chemistry teachers to tend to have a low level (lower-order thinking skills). So that in order to improve the evaluation skills of a pre-service chemistry teacher, in PSE they are equipped with techniques for preparing assessment questions with the Higher Order Thinking Skills (HOTS) criteria.

\subsection{Field Experience Practices (FEP)}

FEP for the pre-service chemistry teachers is conducted at the second stage of the research process. The implementation of FEP is carried out by Islamic University of Kalimantan Muhammad Arsyad Al Banjari Banjarmasin in collaboration with schools in South Kalimantan province. The assessment of FEP was carried out in all schools by all lecturers of the chemistry education department. Because the implementation of FEP is managed by the university, the implementation and assessment aspects used are slightly different from the PSE. This is done by the university to uniformly assess each student-teacher candidate in all different majors (counseling education, sports education, English language education, and others). However, this difference does not have a significant difference and has the same components as the PSE component that has been compiled by the researcher. The components and aspects of assessment in FEP areas are listed in table 2.

\subsection{Relationship Between Pedagogical Skills Excercise (PSE) and Field Experience Practices (FEP)}

Learning by each student is carried out a maximum of three repetitions. The aim is to familiarize students in implementing the learning process in class to reduce various disturbances experienced and maximize the potential possessed by all students [31][32]. The results shown during the process of providing PSE to the preservice chemistry teachers were quite positive. The final PSE score shows an average of 70.99. This shows a significant increase where at the initial meeting the average score of students was 60.5. Through this situation, researchers concluded that during the process of giving PSE students gain reinforcement and habituation in their learning process. Furthermore, in the implementation of FEP, it is known by FEP examiners that pre-service chemistry teachers minimize all the obstacles they get when implementing PSE. pre-service teachers experience obstacles in this case due to lack of experience and involvement in the learning process so that they have not been able to produce meaningful learning [33][34]. Despite experiencing various obstacles, the pre-service chemistry teacher managed to get an increase in FEP scores when compared to the pretest results on the PSE. Chemistry teacher candidates managed to get an average FEP score of 82.5 for all aspects of the assessment. This condition can further be evaluated as consideration for developing subsequent PSE implementation that can accommodate pre-service teachers in strengthening their potential.

\section{CONCLUSION}

Based on the result of the studies, the implementation of Pedagogical Skills Exercise (PSE) has a positive impact in improving the teaching abilities of pre-service chemistry teachers through Field Experience Practice (FEP). PSE can be an alternative solution to overcome various problems experienced by pre-service chemistry teachers such as preparing lesson plans, using language, organizing learning systematics, using time, using variations in learning models, utilizing learning media, and technological literacy in the learning process. In addition, PSE provides training and alternatives for the pre-service chemistry teacher to get used to preparing learning evaluation questions with the Higher Order Thinking Skills (HOTS) criteria.

\section{AUTHORS' CONTRIBUTIONS}

All authors conceived and designed this study. All authors contributed to the process of revising the manuscript, and at the end all authors have approved the final version of this manuscript.

\section{REFERENCES}

[1] J. Sojanah, S. Suwatno, K. Kodri, A. Machmud, Factors affecting teachers technological pedagogical and content knowledge (a survey on economics teacher knowledge), Cakrawala Pendidikan 40(1) (2021) 1-16. DOI: https://doi.org/10.21831/cp.v40i1.31035

[2] D. Werner, Exploring HPE Teachers' Self-Efficacy Toward Technology Integration Bridgewater College, 2020.

[3] L.D. Prasojo, A. Habibi, A. Mukminin, M.F.M. Yaakob, Domains of technological pedagogical and content knowledge: factor analysis of Indonesian inservice EFL teachers, International Journal of 
Instruction 13(4) (2020) 593-608. DOI: https://doi.org/10.29333/iji.2020.13437a

[4] N. Imansari, A. Mukhadis, S. Hadi, H. Elmunsyah, Development of technological pedagogical content knowledge (TPACK) through blended learning for vocational teachers candidates, International Journal of Innovation, Creativity and Change 11(7) (2020) 483-96.

URL: https://www.ijicc.net/images/vol11iss7/11741_Ima nsari_2020_E_R1.pdf

[5] S. Zang, Q. Liu, Z. Cai, Exploring primary school teachers' technological pedagogical content knowledge (TPACK) in online collaborative discourse: an epistemic network analysis, British Journal of Educational Technology 0(0) (2019) 119. DOI: https://doi.org/10.1111/bjet.12751

[6] Depdiknas, Undang-Undang Nomor 14 Tahun 2005, Depdiknas, 2005.

[7] Depdiknas, Peraturan Menteri Pendidikan Nasional Nomor 16 Tahun 2007, Depdiknas, 2007.

[8] N. Dony, M.T. Mashuri, N. Nuriah, Perbandingan media kartu pintar dan truth and dare terhadap hasil belajar materi larutan penyangga di SMAN 1 Alalak, Pancasakti Science Education Journal 4(2) (2019) 115-20, DOI: https://doi.org/10.24905/psej.v4i2.10

[9] P. Pertiwi, N. Dony, M.T. Mashuri, Pengembangan media pembelajaran box question pada materi sistem koloid di MA Siti Mariam Banjarmasin, Dalton: Jurnal Pendidikan Kimia dan Ilmu Kimia 2(2) (2019) 26-35, URL: https://ojs.uniskabjm.ac.id/index.php/daltonjurnal/article/view/2385

[10] Maziah, R.A.A.K. Wardhani, M.T. Mashuri, Studi komparasi model pembelajaran talking stick dan snowball throwing terhadap hasil belajar siswa pada materi tata nama senyawa kelas X SMA Negeri 1 Alalak, Dalton: Jurnal Pendidikan Kimia dan Ilmu Kimia 2(2) (2019) 6-10, URL: https://ojs.uniskabjm.ac.id/index.php/daltonjurnal/article/view/1993

[11] S. Mahmudah, F. Yuridka, M.T. Mashuri, Komparasi pembelajaran kimia menggunakan metode teams-games-tournament dan team-assisted individualization terhadap hasil belajar pada materi ajar tata nama senyawa kelas X SMA Negeri 12 Banjarmasin, Dalton: Jurnal Pendidikan Kimia dan Ilmu Kimia 2(2) (2019) 16-21, URL: https://ojs.uniska-

bjm.ac.id/index.php/daltonjurnal/article/view/1995

[12] Y. Rahma, G.H. Solehah, M.T. Mashuri, Implementasi media permainan ular tangga pada materi tata nama senyawa terhadap hasil belajar siswa kelas X SMA Negeri 10 Banjarmasin, Dalton: Jurnal Pendidikan Kimia dan Ilmu Kimia 2(2) (2019) 28-37, URL: $\underline{\text { https://ojs.uniska- }}$ bjm.ac.id/index.php/daltonjurnal/article/view/1997

[13] Y. Kustyorini, M.T. Mashuri, Penerapan pembelajaran diskusi analogi untuk meningkatkan keterampilan berpikir kritis siswa, Prosiding Seminar Nasional Pakar, Lembaga Penelitian Universitas Trisakti, Jakarta, 2019, pp. 1-5, URL: https://rijurnal.lemlit.trisakti.ac.id/pakar/article/vie $\mathrm{w} / 4373$

[14] N. Rahmawanti, M.T. Mashuri, Nurjanah, Pengaruh media scrapbook terhadap hasil belajar siswa pada materi larutan penyangga, Natural: Jurnal Ilmiah Pendidikan IPA 6(2) (2019) 94-100, DOI: https://doi.org/10.30738/natural.v6i2.5251

[15] M.T. Mashuri, Y. Kustyorini, Perbandingan model pembelajaran student teams achievement divition (STAD) dan grup evaluasi lepas terhadap hasil belajar siswa, Prosiding Hasil Penelitian Dosen, Universitas Islam Kalimantan Muhammad Arsyad Al Banjari Banjarmasin, Banjarmasin, 2019, pp. 162-169, URL: https://ppj.uniska-bjm.ac.id/?p=812

[16] N. Novianti, O. Akhyar, M.T. Mashuri, Pengaruh media dart board terhadap minat belajar kimia siswa pada materi koloid di kelas XI SMA Negeri 12 Banjarmasin, Dalton: Jurnal Pendidikan Kimia dan Ilmu Kimia 1(2) (2018) 29-33, URL: https://ojs.uniska-

bjm.ac.id/index.php/daltonjurnal/article/view/1580

[17] L.U. Ginayah, M.T. Mashuri, R.A.A.K. Wardhani, Pengaruh media teka-teki silang (TTS) kimia 3D terhadap kemampuan kreatif siswa pada materi hidrokarbon kelas X SMA Negeri 12 Banjarmasin, Dalton: Jurnal Pendidikan Kimia dan Ilmu Kimia 1(2) (2018) 14-19, URL: https://ojs.uniskabjm.ac.id/index.php/daltonjurnal/article/view/1578

[18] I.A. Wulandari, M.T. Mashuri, N. Dony, Pengaruh media kotak kartu misterius (KOKAMI) terhadap hasil belajar siswa pada materi pokok hukumhukum dasar kimia di SMA Negeri 12 Banjarmasin, Dalton: Jurnal Pendidikan Kimia dan Ilmu Kimia 1(2) (2018) 1-5, URL: https://core.ac.uk/download/pdf/229028988.pdf

[19] K. Karina, N. Rahmawanti, M.T. Mashuri, Pengaruh media permainan kotak katik terhadap hasil belajar siswa pada materi reaksi redoks kelas X SMA Negeri 1 Alalak, Dalton: Jurnal Pendidikan Kimia dan Ilmu Kimia 1(2) (2018) 6-13, URL: https://ojs.uniskabjm.ac.id/index.php/daltonjurnal/article/view/1577 
[20] Y. Sari Y, G.H. Solehah, M.T. Mashuri, Pengaruh penggunaan media permainan kartu UNO pada materi senyawa hidrokarbon terhadap hasil belajar siswa, Vidya Karya 33(1) (2018) 35-41, URL: https://ppjp.ulm.ac.id/journal/index.php/JVK/articl e/view/5391

[21] A.D. Subroto, M.T. Mashuri, O. Akhyar, Implementasi permainan tradisional berbasis budaya lokal pada materi pokok koloid untuk meningkatkan kemandirian belajar siswa kelas XI SMAN 10 Banjarmasin, Dalton: Jurnal Pendidikan Kimia dan Ilmu Kimia 1(1) (2018) 11-15, URL: https://ojs.uniska-

bjm.ac.id/index.php/daltonjurnal/article/view/1496

[22] M. Marlinasari, M.T. Mashuri, G.H. Solehah, Pengaruh media pembelajaran komik terhadap minat belajar kimia siswa pada materi koloid di kelas XI MIA MAN 1 Banjarmasin, Dalton: Jurnal Pendidikan Kimia dan Ilmu Kimia 1(1) (2018) 3033, URL: https://ojs.uniskabjm.ac.id/index.php/daltonjurnal/article/view/1499

[23] G.H. Solehah, M.T. Mashuri, Penerapan pembelajaran kooperatif tipe student team achievement division berbasis islami untuk meningkatkan motivasi belajar kimia, Prosiding Hasil Penelitian Dosen, Universitas Islam Kalimantan Muhammad Arsyad Al Banjari Banjarmasin, Banjarmasin, 2018, pp. 148-154, URL: $\quad$ http://ppj.uniska-bjm.ac.id/prosidingpenelitian/

[24] H. Karolina, M.T. Mashuri, F. Yuridka, Pengaruh media kartu isomer bergambar pada materi hidrokarbon terhadap hasil belajar siswa kelas $\mathrm{X}$ SMA Negeri 1 Alalak, Dalton: Jurnal Pendidikan Kimia dan Ilmu Kimia 1(1) (2018) 23-29, URL: https://ojs.uniska-

bjm.ac.id/index.php/daltonjurnal/article/view/1498

[25] N.K.A. Sukarsih, R.A.A.K Wardhani, M.T. Mashuri, Pengembangan kartu remi kimia menggunakan model pembelajaran TGT (Teams Games Tournament) terhadap hasil belajar siswa pada materi pokok sistem koloid kelas XI SMA KORPRI Banjarmasin, Dalton: Jurnal Pendidikan Kimia dan Ilmu Kimia 1(1) (2018) 16-22, URL: https://ojs.uniska-

bjm.ac.id/index.php/daltonjurnal/article/view/1497
[26] J. Gess-Newsome, N.G. Lederman, Examining Pedagogical Content Knowledge, Kluwer Academic Publishers, 1999.

[27] A. Berry, P. Friedrichsen, J. Loughran, ReExamining Pedagogical Content Knowledge in Science Education, Routledge, 2015.

[28] A.D. Morrison, K.C. Luttenegger, The Qualitative Report, 2015.

[29] J.H Van Driel, N. Verloop, W. de Vos, Journal. of Research in Science Teaching, 1998.

[30] P.L. Grossman, The Making of a Teacher: Teacher Knowledge and Teacher Education, The Teacher College Press, 1990.

[31] S.K. Abell, International Journal of Science Education, 2008.

[32] J. Barnett, D. Hodson, Science Teacher Education, 2001.

[33] R.W. Bybee, Learning Science and The Science of Learning, NSTA Press, 2002.

[34] R.W. Bybee, The Teaching of Science $21^{\text {st }}$ Century Perspectives, NSTA Press, 2010. 